\title{
Prediking as Kommunikasie
}

\author{
M J du P Beukes
}

Indien ons teologies-wetenskaplik te werk wil gaan, moet ons ons vertrekpunt neem in die Bybel. Ons sit egter met die probleem dat ons besondere tema nêrens in die Bybel aan die orde gestel word of uitgewerk word nie. Nêrens in die Bybel kry ons ' $n$ definisie van of prediking òf kommunikasie nie. In die Bybel, kry ons myns insiens ook nie ' $n$ volledige weergawe van 'n preek soos ons dit vandag ken nie. Die Bybel bied hoofsaaklik aan ons breë lyne van hoe die verkondiging gefunksioneer het gedurende die "openbaringstyd".

\section{2}

Feitlik elke beoefenaar van die Praktiese Teologie het op een of ander wyse gepoog om 'n definisie te gee van prediking. Prof J I de Wet beskryf die prediking as ' $n$ liturgiese gestalte van die kerklike verkondiging. Verkondiging is breed omskryf, die verklaring en die toepassing van die Skrif met betrekking tot die Persoon, Woord en werk van Jesus Christus met die oog op stigting en vermeerdering van geloof. Die prediking is dan daardie deel van die verkondiging wat voltrek word in die erediens vergaderde gemeente.")

3

In aansluiting by Sweazey ${ }^{2)}$ wil dr C Heys ${ }^{3)}$ nie ' $n$ definisie gee van kommunikasie nie, maar eerder 'n breë omskrywing daarvan.

Kommunikasie is ' $n$ proses. Hierdie proses is afhanklik van bepaalde komponente.

\section{Die bron}

Kommunikasie het altyd ' $n$ vertrekpunt. Hierdie vertrekpunt noem ons die bron. In ons geval kan ons sê die bedienaar van die Woord is die bron. Voordat die bron begin praat, gaan daar reeds bepaalde invloede uit. Hovland en Weiss ${ }^{4)}$ het getoon dat die kommunikasie soveel meer effektief is as die bron van die kommunikasie geloofwaardigheid besit. "Hoe iemand is, daarmee staat of valt wat hij

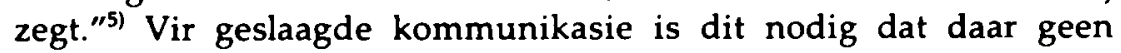
kontradiksie tussen die bron se woorde en dade is nie. 


\section{Kodifisering}

Dit wat gekommunikeer word, word eers gekodifiseer. Dus die bron sit die inhoud van sy gesprek eers om in simbole. Die gevaar is dat ' $n$ bepaalde simbool nie altyd vir alle mense dieselfde betekenis het nie. Vergelyk onder andere die verskillende betekenisse van "leer".

\section{Medium}

Die inhoud wat gekodifiseer is en sy bestemming moet bereik, doen dit deur verskillende media. Die bestemming en die doel bepaal in 'n baie groot mate die media wat gebruik word.

\section{Dekodifisering}

Die bestemming ontvang die seine van die simbole via die media. Voordat die inhoud "bemeester" is, moet die bestemming dit eers dekodifiseer. "Kommunikasie vind juis plaas wanneer die een persoon geleer het om dieselfde betekenisse aan bepaalde simbole te heg as die ander.." ${ }^{16)}$ Martin Joos ${ }^{7}$ wys daarop dat die mees geleerde persoon in ' $n$ bepaalde vakgebied selde meer as $80 \%$ van die kommunikasie in verband daarmee verstaan soos die bron dit bedoel het. Die ervaring of kennis van die bestemming met betrekking tot die bepaalde onderwerp bepaal in hoe 'n mate die bestemming se dekodifisering gaan ooreenstem met die bron se oorspronklike bedoeling.

\section{Bestemming}

Die bestemming is die teken van die kommunikasie en kan of ' $n$ individu of ' $n$ massa wees. Met die oog op suksesvolle kommunikasie wil Fourie ${ }^{8)}$ dat daar rekening gehou moet word met:

\section{Demografiese eienskappe}

Soos geslag, ouderdom, nasionaliteit, beroep, opvoeding, inkomste, woonbuurt, sosiale affiliasies, politieke affiliasies, godsdienstige affiliasies en groepaffiliasies.

\section{Begripsvermoë}

Hiervolgens weet die bron wat hy moet herhaal en wat hy eenvoudig moet stel. 


\section{Kommunikatiewe vatbaarheid,}

soos gesindhede, motiewe, waardes, opinies en emosies wat 'n bepaalde invloed op 'n bepaalde kommunikasieproses kan hê.

\section{Kommunikatiewe gewoontes}

Die effektiwiteit van die kommunikasie sal baie hoër wees as gebruik gemaak word van die media en die tye waarvoor daar by die bestemming 'n voorkeur is.

Via 'n lang pad met baie invloede bereik dit wat gesê is sy bestemming. Die bedoeling is dat die bestemming die boodskap net soos die bron dit bedoel het, moet ontvang. Die bron laat sy boodskap hoor met ' $n$ bepaalde doel. Dit wil sê in die kommunikasieproses gaan dit om veel meer as woorde. Die woorde is slegs 'n middel om 'n bepaalde resultaat te bereik. Die kerk in sy prediking gebruik hierdie middel dankbaar as 'n middel om met sy prediking bepaalde resultate te bereik.

In hierdie referaat, gaan dit om die prediking as kommunikasie in die breedste moontlike sin - dit wil sê die prediking as iets wat nie in die lug hang nie, maar by die hoorders uikom en bepaalde reaksie by hulle op daardie oomblik en later tot gevolg het.

4

Sedert die Tweede Wêreldoorlog is daar 'n groot onbehae met betrekking tot die prediking. Baie beoefenaars van die homiletiek is dit eens dat die prediking in die 20ste eeu nie meer die gewenste effek het nie. Kommunikasie in die breë sin van die woord het vanweë verskeie faktore 'n onmoontlikheid geword.

\section{W D Jonker"}

noem die volgende faktore as verskynsels wat belemmerend inwerk op die prediking as effektiewe kommunikasie.

\section{Die geleentheid om te antwoord op die prediking ontbreek}

Goeie kommunikasie is gewoonlik daar aanwesig waar die hoorder of die ontvanger die boodskap ten volle kan "hoor" en daarop kan antwoord. Kommunikasie kom altyd van twee kante. Dit geskied in die vorm van woord en weerwoord of van gebaar en antwoordende gebaar. 
412 Die moontlikheid om vas te stel of daar 'n "geraas" tussen die prediker en die hoorder is ontbreek

Verskillende faktore kan die oorsaak wees dat die hoorder nie die boodskap hoor nie of dit verkeerd hoor. Dit kan alleen vasgestel word as daar op ' $n$ bepaalde stadium terugvoering van die kant van die hoorder af kom. Hierdie terugvoering vind normaalweg nie plaas nie.

\section{Dit is wetenskaplik vasgestel dat kommunikasie op die wyse van} die prediking nie die hoogste moontlike effektiwiteit het nie

Die hoogste kommunikatiewe effektiwiteit word bereik tydens persoonlike gesprekke en in die tweede plek met groepsbespreking. ("David A Radius wys daarop dat die gemiddelde luisteraar in die kerk byvoorbeeld, slegs $15 \%$ kan onthou van die betrokke kommunikasie wat tot hom gerig is. Dit is waarom dosente en adverteerders metodes soek om die boodskap op so 'n manier oor te dra dat die bestemming dit ten volle sal begryp en kan onthou." ${ }^{10}$ )

414 Die lidmate moet elke Sondag luister na prediking wat basies altyd dieselfde boodskap het

Die kernboodskap van die Skrif is aan die orde met elke preek van die wieg tot by die graf.

\section{Predikers is nie altyd goed voorberei nie}

Preke wat afgelees word, verlaag die kommunikatiewe effektiwiteit.

\section{Tydens prediking word die minimum hoeveelheid sintuie van die mens betrek}

Dit is wetenskaplik vasgestel dat ' $n$ gemiddelde persoon as hy ' $n$ bepaalde stuk lees, onthou hy na 'n paar dae slegs $10 \%$ daarvan, as hy dit slegs hoor net $20 \%$, as hy dit slegs sien $30 \%$, as hy dit lees, hoor en sien $50 \%$ en as hy dit lees, hoor, sien en daarna oorvertel $75 \%$.

417 Baie woorde wat tydens die prediking gebruik word, is onbekend Baie begrippe word as bekend veronderstel terwyl dit nie die geval is nie. 


\section{Die gehoor bestaan uit te ' $n$ groot verskeidenheid.}

In die meeste gemeentes is daar groot ouderdomsverskille, sosiale verskille, akademiese verskille, beroepsverskille en baie ander verskille tussen die luisteraars.

\subsection{H J C Pieterse ${ }^{12)}$}

het die faktore wat die kommunikatiewe effektiwiteit van die prediking beïnvloed in baie breër trekke beskryf. Die probleem hier ter sprake, noem hy die nood van die prediking.

\section{Veranderde wêreldbeeld}

Kopernicus (1473-1543) het met sy nuwe wêreldbeeld 'n skud deur die wêreld laat gaan. Kopernicus se wêreldbeeld is geleidelik vervang met ' $n$ nuwe beeld wat na vore gekom het na die sterrekundige ontdekkings van 1925 en 1950 . Dit het gelei tot die verwerping van die voor-wetenskaplike wêreldbeeld van die oud-Oosterse wêreld. Dit het ook gelei tot 'n konflik tussen geloof en wetenskap. Die gevolg was dat die sekondêre wêreld al hoe meer die natuurwetenskap gekies het as die enigste moontlikheid om die waarheid te ontdek. Die natuurwetenskaplike lokaal het gevolglik aantrekliker geword as die "voorhowe van die huis van die Here."

\section{Descartes en die Aufklärung}

het ' $n$ besondere stoot aan die mens as denkende subjek gegee. Die rede van die mens is so verhef dat dit beskou is as die enigste weg om by die waarheid uit te kom. Dit is die enigste weg waarlangs jy God kan ken en waarmee jy die regte pad kan kies wat jy moet bewandel. Daar word eerder geluister na die verstand, die gevoel, die wil as na die prediking.

\section{Die ontdekking van die sogenaamde "Geschichtlichkeit" van die menslike bestaan het meegewerk om die tradisionele gesagsbindinge van Skrif en prediking af te breek.}

"Die mens staan in die verloop van die geskiedenis en is besig om geskiedenis te maak. Die Skrif byvoorbeeld word gesien as 'n historiese gegewendheid wat in die loop van die menslike geskiedenis tot stand gekom het. Daarom is daar geen finale openbaring in die Skrif wat vir alle tye geld nie, maar sy gesag is histories bepaald - dus relatief. ${ }^{\prime 13)}$ Uit hierdie proses het die histories-kritiese metode ge- 
groei. Met die verstand word vasgestel wat alles in die geskiedenis gebeur het. "Alles wat nie ooreenstem met die siening van die betrokke ondersoeker se beeld van wat waar is in sy dag nie, word weggesny en beskou as tydgebonde en agterhaalde vasstellingswyses. ${ }^{.14)}$

424 Die mens tot wie die prediking gerig is, is 'n gesekulariseerde wese wat leef in ' $n$ gesekulariseerde wêreld.

In so 'n mate het die sekularisasie die wêreld oorspoel dat God vir hierdie wêreld ' $n$ vreemdeling geword het. ${ }^{15)}$

\section{3}

Leonhardt Fendt ${ }^{16)}$ noem die vooringenomendheid met betrekking tot die inhoud van die Bybel as een van die belangrikste faktore wat die kommunikatiewe effektiwiteit van die prediking raak. Baie lidmate skakel by voorbaat af as sekere temas soos die drie-eenheid, die uitverkiesing aan die orde kom in die prediking. Die moderne mens wil slegs prediking hoor wat suiwer handel oor die hier en die nou.

\section{5}

Feitlik elke beoefenaar van die homiletiek worstel met die vraag na die sinvolle oorbrugging van die kommunikasiegaping tussen prediker en luisteraar. Oplossings met betrekking tot hierdie saak loop oor 'n baie breë linie.

\section{Melanchton ${ }^{17}$}

het die "leer"-aspek van die prediking al hoe meer beklemtoon. "Fur ihn ist die doctrina evangelii ausschliesslich Inhalt der Praigt." ${ }^{18)}$ As gevolg van die rasionalistiese strominge is die prediking al hoe meer in ' $n$ intelektualistiese hoek gedrywe. Die leeraspek word so beklemtoon dat die kansel na 'n kateder en die kerk na 'n klaskamer lyk. Hierdie vasvang van die prediking in 'n dorre leersisteem het gelei tot die gebrek aan kommunikasie.

\section{2}

Deur middel van die Piëtistiese ${ }^{19)}$ vroomheidsprediking van Spenser en Francke, die metodisties ${ }^{20}$ prediking van Wesley en Whitefield, is daar gepoog om die lidmaat weer ten volle by die prediking te betrek. 


\section{Schleiermacher, ${ }^{211}$}

sterk onder die invloed van Spinoza, Hegel, Kant, Fichte, Schelling en die Piëtiste, wou met sy subjektivistiese uitgangspunte die kloof tussen prediker en luisteraar oorbrug. Deur sy ervaringsteologie wou hy die innerlike bekering tot principium van die prediking verhef. "Darum ist Predigt für ihn wesentlich selbsmitteilung des Predigers." ${ }^{22)}$

\section{4}

Na die voortbouing van die Liberalistiese Kultuurprediking op die prediking van Schleiermacher, was dit veral $K B a r t h^{23)}$ wat besef het dat die verskuiwing van die klem van God na die mens geen wesenlike verbetering gebring het in die kommunikasieproses nie. As die klem verskuif word van God na die mens is dit in elk geval 'n tendens wat in stryd is met die Bybel self.

Barth beklemtoon die kwalitatief-oneindige verskil tussen God en mens. God kan alleen in sy openbaring geken word. Hierdie openbaring van God is die vleesgeworde Woord Jesus Christus. Buite hierdie openbaringsgestalte, Jesus Christus, is daar slegs tekens wat diensbaar gemaak word aan die openbaring. Hierdie tekens verwys na Jesus Christus en roep ook op tot die geloof in Hom. Tot hierdie tekens behoort veral die Bybel en die prediking. Die Bybel en die prediking is daarom nie self openbaring nie. Beide Bybel en prediking verwys net na en getuig net van die openbaring. Die Skrif is bloot ' $n$ menslike poging om die openbaring te betuig. Slegs vir sover as wat die Skrif getuienis van Christus gee, is dit' $n$ betroubare produk van die openbaring. Die Skrif is nie sonder meer Woord van God nie, maar word Woord van God wanneer dit Hom behaag om Hom daarmee aktueel aan ons te openbaar. Besondere klem word gelê op die aktualisering van die Skrifwoord deur die krag van die Heilige Gees. So gesien beteken dit dat die prediking alleen vrugte kan oplewer as dit getuie is van die waarheid van Jesus Christus soos die Skrif van Hom getuig.

\section{5}

R. Bultmann ${ }^{24)}$ se teologiese denke word deurgaans gekenmerk deur 'n intense drang om die Nuwe-Testamentiese boodskap vir die kontemporêre tyd assimileerbaar te interpreteer. Dit is 'n worsteling om die inhoud van die Bybelse boodskap so in die situasie te verklaar dat dit die mens in sy totaliteit raak. Bultmann se betekenis lê daarin dat hy in heftige reaksie teen alle objektiewe en tydlose in die prediking, die boodskap weer aktueel wil interpreteer vir sy tyd. 
Hy wou die Nuwe Testament aktueel en verstaanbaar maak vir die moderne lewensgevoel. Verstaan beteken vir hom dat ons telkens opnuut die Skrifteks in ons eie eksistensie verstaan en realiseer. Hy maak veral van die vormhistoriese en die godsdienshistoriese metode gebruik om die evangelie aktueel en verstaanbaar te maak vir die moderne mens. Hy beweer dat baie van die Nuwe-Testamentiese temas herleibaar is tot die fantasieë van Christus se volgelinge, die mitologie van die Joodse Apokaliptiek en die verlossingsmites van die Gnostiek. Daar kan nie verwag word dat die moderne mens hierdie wêreldbeeld moet aanvaar nie. Eers as ontmitologisering plaasgevind het, is hierdie wêreldbeeld aanvaarbaar en kommunikasie in die volle sin van die woord moontlik.

\section{6}

Volgens $\mathrm{K} \mathrm{Dijk}{ }^{26)}$ sal aan die volgende aandag gegee moet word om die prediking sy werklike aktualiteit te laat behou. Dit moet diens van die Woord wees. Dit moet diens van Jesus Christus deur die Heilige Gees wees. Dit moet bedien word deur 'n bedienaar van die Woord. Dit moet bedien word aan 'n gemeente. Verder moet bepaalde verbande gehandhaaf en reg gebruik word: die verband met die eksegese met die belydenis en die dogma, met die geestelike ligging van die gemeente, die psigologiese en sosiologiese gesteldheid van die gemeente en die fasiologie.

\section{H Jonker ${ }^{26)}$}

het in sy alombekende "Aktuele Prediking" op feitlik elke bladsy gepoog om die prediking te verhef tot 'n gestalte van die kerklike verkondiging wat werklik by die hoorders uitkom en vrugte in hulle lewe voortbring.

Jonker wys bepaalde verskynsels af wat volgens hom in die pad staan van sinvolle prediking:

(1) slegs die verklaring van objektiewe waarhede, sonder dat die mens eksistensieel daarby betrokke is;

(2) die beklemtoning van die subjektiewe as die wesenlike van die prediking. Hier is die religieuse mens aan die woord en raak die appellerende Woord verborge onder die sluier van menslike gevoelens;

(3) die dialoog in die eksistensiële kommunikasie, soos dit onder meer deur Karl Jaspers in die moderne denke ingevoer is. "De Communicatie bij Jaspers verwerpt alle objectiviteit en laat zich aan geen enkele objectiviteit bindin ... Het gaat hier niet om mededeling of overdracht van waarheid, maar realisering van 
eigen waarheid, vanuit de eigen zelfzekerheid. ${ }^{227}$ Dit beteken uiteindelik dat die evangelie slegs waar is as dit deur my as waar beoordeel word.

Jonker pleit vir aktuele prediking. Dit is alleen moontlik as die hermeneutiese funksie van die predikant verstaan word in die sin van: vertel, duidelik maak aan ander. Vir die regte vertolking is drie sake nodig:

(1) "die objektiewe vertaling van het objectief gegevene;

(2) het deurschouwen van de zaak van de dichter of schrijver in zijn situasie, de zogenaamde "Wesenschau";

(3) de Vergegenwärtung, realisering, actualisering van die zaak in het heden, het waarachtig doen zijn van de Waarheid in het heden." ${ }^{28)}$

In hierdie proses word daar beweeg vanaf die Woord na die situasie (aktuele prediking) en nie van die situasie na die Woord nie (aktualistiese prediking).

\section{H D A du Toit, ${ }^{29)}$}

in aansluiting by Rasker, bepleit homiletiese eksegese soos hy dit noem. Daarmee word bedoel dat die prediker se oor en oog reeds tydens sy voorbereiding gerig moet wees op sy gehoor.

\section{9}

Met die oog op effektief-kommunikatiewe prediking pleit $G J$ Kotze $e^{30)}$ dat met die volgende eise rekening gehou word:

\section{Die eis van die aanknopingspunt:}

Anders as K Barth wat gesê het "Ich halte die analogia entis für die Erfindung des Antichrist" ${ }^{\prime 31}$ ) wil Kotzé baie sterk vashou aan die gedagte van die aanknopingspunt. Onder die aanknopingspunt word verstaan dat God in sy openbaring iets by die mens aantref waarby $\mathrm{Hy}$ in sy genadige bemoeiing by hom kan aansluit. In die mens is geleë ' $n$ ontmoetingspunt, ' $n$ dialogiese moontlikheid waarby die prediking kan en moet aansluit ... Die waarheid waarmee die prediking voortdurend rekening moet hou, is dat al het die mens deur die tragiese sondeval sy gemeenskap met God en met die medemens radikaal verloor, sy kommunikasie met God deurbreek, hy nog altyd ' $n$ religieuse verbondenheid behou, wat hom aanspreeklik en aanspreekbaar maak vir die Woord van God. Die mens het as gevolg van die droewe verhaal van die sonde en die daarmee 
gepaardgaande verbreekte dialoog met God, nie 'n dier of 'n klip geword nie, maar' $n$ mens gebly, in die moontlikheid gebly om deur God gekonfronteer te word." ${ }^{32)}$

\section{Die eis van dialogiese spanning tussen Woord en situasie}

\section{Die gerigtheid op die Woord}

Alleen die gelade inhoud van die Skrif vorm die unieke boodskap wat gehoor moet word. Om werklik by hierdie boodskap uit te kom, sal die onvervangbare funksies van die eksegese beklemtoon moet word. Wie waarlik bedienaar van die Woord wil wees, sal met alle erns moet probeer om agter die oorspronklike bedoeling van die teks te kom. Hy bepleit veral perikoopprediking.

\section{Die gerigtheid op die situasie}

Hiermee word bedoel die prediking moet deurgetrek word om die mens te spreek in die konkrete situasie waarin hy hom bevind. Die gang van die prediking is van die teks na die situasie en nie omgekeerd nie. As die gang van die situasie na die teks is, word die teks slegs gebruik as 'n vertrekpunt vir die prediker se eie gedagtekonstruksies. So word dit moontlik om dieselfde preek vir verskillende geleenthede te gebruik. Jy kies net altyd 'n ander teks as jou vertrekpunt.

\section{Profetiese gerigtheid}

Die koningskap van Jesus Christus moet uitgeroep word oor die ganse menslike lewe in al sy openbaringsgestaltes. Die kerk sal moet waak om hom alleen besig te hou met die onsterflike siel van die mens. Langs hierdie weg word die evangelie gereduseer tot ' $n$ veilige polis net vir die toekomstige saligheid en 'n niksseggende vir die hier en die nou.

\section{Eskatologiese gerigtheid}

Die prediking moet boodskap wees van die volle oorwinning, die hoop en die bevryding wat deur Jesus Christus gekom het.

\section{Die eis van die regte sielkundige benadering}

"Een van die allervernaamste aksente vir die Skrifprediking vir ons dag is die van die regte sielkundige benadering. Indien die kerk in 
sy verkondigingsakte nie hiermee rekening hou nie, sal hy onverbiddelik beland in een van die gevaarlikste versoekinge, naamlik om die nuwe situasie van ons dag met ou metodes te beantwoord. Dit kan daartoe lei dat die kerk misluk om sy eie tyd te ken en aan te spreek. ${ }^{\prime \prime 3)} \mathrm{Hy}$ pleit dat die kerk in sy prediking meer gebruik sal maak van die gegewens wat die aanverwante vakke bied, veral die psigologie en meer bepaaldelik die psigoterapie.

\section{Die eis van gepaste taalinkleding}

Die boodskap moet vertaal word in verstaanbare eenvoudige taal. Die taal moet die konkrete taal van die dag wees. Vreemde woorde en lang sinne moet vermy word. 'n Aangeplakte professionalistiese houding en spraakwyse is meer afbrekend as opbouend.

\section{Die eis van effektiwiteit}

Die preek moet goed uitgewerk word. Dit moet so ver as moontlik voorgedra word sonder ' $n$ manuskrip. Dit moet oorgedra word in egtheid en nederigheid.

596 Die eis van kragvolle prediking deur die Heilige Gees en die gebed As die kerk die mens van ons eeu met kragvolle Woordverkondiging wil konfronteer, sal hy homself opnuut rekenskap moet gee van die besondere verhouding tussen Woord en Gees. Beide die verkondiging van die Woord en die verstaan daarvan is alleen moontlik deur die werking van die Heilige Gees. Beide prediker en lidmaat moet ' $n$ gesonde gebedslewe hê.

\section{Die eis van rekening hou met die moderne mens}

\section{1}

Baie van die moderne mense is nog in naam lidmate van die kerk, maar innerlik is hulle volkome vervreemd. Aangaande Jesus Christus het hulle reeds' $n$ gekondisioneerde houding ingeneem.

\section{2}

Hy is 'n outonome, 'n mondige wat weier om krities en outomatief beperk en betoespraak te word. Hy verlang dat daar liefdevol na hom geluister sal word. 


\section{3}

Hy is eksistensieel in die wêreld betrokke oor ' $n$ baie breë linie. Dit het daartoe gelei dat groothede uit ander dimensies vir hom onsaaklik geword het. Hy het buitendien nie daarvoor tyd nie.

\section{4}

Die kerk met sy funksionering is vreemd aan sy leefwêreld en daarom voel hy byvoorbeeld beswaard teen die kerk.

\section{5}

Harde feite is vir hom die een en die al. Aan vasstaande realiteite, bewysbare groothede het hy sy lojaliteit toegesê. Die tegniek, die staat, die produksie het vir hom die moderne godsdiens geword.

\section{6}

Die materialisme is die grootste koning van sy lewe.

\section{7}

Hy ken geen verhewe doelstellings meer nie.

\section{0}

In sy proefskrif "Skrifverstaan en Prediking" vra $H$ J C Pieterse die vraag: "Hoe kan die prediker vandag uit die Skrif as historiese dokument ' $n$ waarheid oorbring na die gemeente toe wat meer as net van historiese interesse is, wat pro me eksistensieel relevant is in ons lewens vandag?"'34)

$\mathrm{Na}$ 'n deeglike behandeling van Ebeling se hermeneutiese teologie as antwoord op die nood van die prediking sien hy die oplossing van die probleem as geleë in "vertaling, translatio".

Hierdie vertaling beteken nie slegs dat die sogenaamde kanseltaal vervang word met gewone alledaagse taal nie. Dit gaan veel dieper. Dit is die vertaling van die Bybel in hierdie werklikheid in. "Vertaling beteken dat die intensie van die teks in die hede tot sprake kom. Die Woord van God word deur die vertaling segbaar in die konkrete situasie van die gemeente. Dit beteken nie dat die eksegese gedoen word en dat daar dan slegs ' $n$ paar praktiese opmerkings bykom om die hele saak prakties gerig te maak nie. Die eksegese bring self die inhoud van die teks na vore en hierdie inhoud word so vertaal dat 
dit ' $n$ boodskap het vir die mens van hier en nou. ${ }^{\text {(35) }}$ Egte vertaling beteken dat die kerugma uit sy kontingente historiese situasie deur die eksegese onthul word en in die prediking in die taal van die kontingente historiese situasie gehul word. Die kerugma moet met die vlees en die bloed van die hede, vir die spesifieke gemeente tot wie dit Sondag kom, geklee word." ${ }^{36)}$ Om so te vertaal in die taal van sy tyd het die prediker hulp nodig. Hierdie hulp word gebied deur die teologie en in die besonder deur die dogmatiek.

\section{1}

Volgens Barkley Wolf $\mathrm{f}^{3 n}$ het die kommunikatiewe effektiwiteit van die prediking verlore gegaan vanweë die swak aanbieding van die preke. Hy pleit vir ' $n$ meer illustrerende wyse van prediking. In hierdie verband sê hy is daar baie sekulêre stof wat gebruik kan word as illustrasie in die preek. Hy verwys na Shakespeare, Ibsen, Churchill, films van Ingmar Bergman en veral verskillende fabels "omdat zij meestal geen moraal verkondigen maar moraal zijn. Het zijn dikwijls diepzinnige en scherpe commentaren op de morele vraagstukken van het leven. De fabels van Lafontaine zijn in dit opzicht eerste klas materiaal. En stel eens, dat iemand zou willen preken over Korinthe 12 - het lichaam en de ledematen en hun onderlinge afhanklijkheid -, zou dan de Fabel van Aesopus geen dienst kunnen doen?",38)

\section{2}

Vir Dorothee Sölle ${ }^{39)}$ sal die probleem opgelos wees as die prediking soos dit volgens haar hoort, politieke teologie is. "Politieke theologie is theologische hermeneutiek die iets anders wil zijn dan een ontologische of een existentieel interpreterende theologie en die een interpretatieperspektief biedt waarin de politiek wordt gezien als de alles omvattende en beslissende ruimte waarbinnen de christelijke waarheid praxis moet worden."40) Hier is dit nie meer die Woord se inhoud self wat die inhoud van die prediking bepaal nie, maar die gedagtes van die prediker met betrekking tot sy eie vooropgestelde ideale maatskappy. Velema sê in sy kommentaar op die politieke prediking: "Men kan zeggen dat hier de gereformeerde omschrijving van wat prediking is precies wordt omgekeerd. Zij luidt: Prediking is uitleg en toepassing van de teks. Hier wordt het: door de toepassing krijg je de juiste uitleg. Als een tekst niet bevrijdend werkt, is ze ook niet goed verklaard. ${ }^{(41)}$ 


\section{Dieter Trautwein ${ }^{42}$}

het in sy "Kerkdienst als leerproces" met die mees radikale denke in hierdie verband voor' $n$ dag gekom. Die prediking sal volgens hom slegs ' $n$ verandering in lewenshouding aanbring as dit daarin slaag om die gemeente tot kreatiewe denke aan te spoor. Om dit te kan doen moet die prediking ' $n$ leerproses word of liewer' $n$ leerervaring. "Leren is meer dan vergaren van kennis in schoolse zin. Het is een wisselwerking tussen mens en leefwereld. Vandaar dat Leren verder gaat dan een theoretische verbale kennis of een praktisch-motorische daad." ${ }^{\prime 33)}$

Om hierdie leerproses suksesvol te laat verloop word ' $n$ werkgroep saamgestel. Saam met die predikant werk hulle die preek uit en bied dit aan. Tydens die aanbieding word van moderne leerwyses soos groepsbespreking, rollespel, paneelbespreking ensovoorts gebruik gemaak. Deur gebruik te maak van 'n werkgroep wat saam met die predikant die preek uitwerk en deur baie persone daarby in die erediens te betrek, word "de democratisering van de verkondiging bevorderd. ${ }^{\prime 44)}$

\section{4}

Tydens Instructa ' $80^{45}$ ) is met ' $\mathrm{n}$ paneelbespreking besondere aandag gegee aan die gebruik van visuele hulpmiddels tydens die prediking. Uit die bespreking het dit geblyk dat die deelnemers van oordeel is dat sekere visuele hulpmiddels wel ten dienste van die gewone prediking gebruik kan word om die kommunikatiewe effektiwiteit te verhoog sonder dat bepaalde prinsipiële beginsels in verband met die prediking in gedrang kom. Daar is gedink aan die volgende: ' $n$ kort samevatting van die kern van die boodskap op ' $n$ doek deur middel van 'n truprojektor en 'n kort opsomming van die hoofgedagtes van die preek wat na die diens in afgerolde vorm by die deure uitgegee word.

\section{6}

Nadat ons na baie mense op baie plekke en verskillende tye geluister het, gaan ons na ons primêre bron, naamlik die Bybel. Voordat ons by die Bybel uitkom, moet ons miskien net eers ' $n$ vinnige draai by ons belydenisgeskrifte gaan maak.

\section{1}

Die Nederlandse Geloofsbelydenis maak slegs melding dat daar in die kerk dienaars van die Woord moet wees om te preek en dat die prediking deel is van die merktekens van die ware kerk. ${ }^{46}$ ) 
Die Heidelbergse Kategismus noem die prediking as die vernaamste moment van die Sondagviering. ${ }^{47}$ Die verkondiging is ' $n$ besondere instrument in die "hand" van die Heilige Gees. Die Heilige Gees gebruik dit as 'n middel om die geloof in mense se harte te werk en as 'n middel wat saam met die sakramente ' $n$ mens se geloof versterk ${ }^{48}$ Hierdie geloof is kennis van die Woord van God en vertroue in die God van die Woord. ${ }^{49)}$

\section{3}

Die Dordtse Leerreëls praat breër as die ander twee belydenisskrifte oor hierdie saak. Die verkondiging van die evangelie is ' $n$ middel wat God gebruik met die oog op die stigting en die vermeerdering van die geloof in Jesus Christus. ${ }^{50)}$ As gevolg van die verkondiging volg na die geloof die bekering en die getuie wees van God se dade in die wêreld. ${ }^{51)}$ As gevolg van die verkondiging kan die gelowiges reg verstaan en die dinge onderskei waar dit op aankom. Deur middel van die verkondiging "vermuft" die Heilige Gees "wat hard is". Hy besny wat onbesnede is. In die wil stort Hy nuwe hoedanighede in en maak dat die wil wat dood was, lewend word: wat boos was, goed word; wat nie wou nie, nou inderdaad wil; wat weerspannig was, gehoorsaam word; Hy beweeg en versterk die wil sodat dit soos 'n goeie boom vrugte van goeie werke kan voortbring." ${ }^{12)}$

Dit beteken hoegenaamd nie dat die verkondiging outomaties altyd hierdie vrugte tot gevolg sal hê nie. Die vrugte bly die vrymatige resultaat van die Heilige Gees se werk. Vanweë sommige mense se eie "sorgeloosheid" kry hulle nie deel aan hierdie vrugte wat die Heilige Gees gee deur middel van die verkondiging nie. ${ }^{53}$

Net soos in die geval by die Heidelbergse Kategismus word die bediening van die Woord en die sakramente hier in 'n baie nou verbondenheid met mekaar geteken. ${ }^{54)}$

\section{1}

Die kommunikasie-aspek neem in die Bybel 'n besondere plek in. God word in die Bybel beskryf as die God wat op baie maniere met die mens "kommunikeer". ${ }^{55}$ Voor die sondeval was die kommunikasie tussen God en mens in die Paradys 'n doodnatuurlike saak. God het tot die mens gespreek en die mens het geantwoord op God se spreke.

Vanweë die sondeval het die mens die kommunikasiekanaal tussen hom en God verstop. God self het hierdie kommunikasiekanaal oopgehou met sy handelinge en spreke deur middel van die verkies- 
ing van die volk Israel. As uitverkore, geroepe Volk van God moes Israel deur woord en daad, deur offer en lewe antwoord gee op God se kommunikatiewe handelinge met hulle.

\section{2}

In die volheid van die tyd het God met die mens gekommunikeer deur die Woord wat vlees geword het, Jesus Christus. Die wonder van hierdie kommunikasie is "die onuitspreekbare word vlees, word geartikuleer in mensewoorde en begrippe (inkarnasie en inverbasie). ${ }^{\text {"56) }}$

Hierdie gebeure vind plaas tot heil en verlossing van die mens. Hierdie openbaring van God, hierdie "in die vlees geworde kommunikasie van God" vra reaksie, antwoord van die kant van die mens. Die antwoord wat gevra word, is geloof in Jesus Christus - geloof met die dimensies van volkome verwagting en uit dankbaarheid 'n lewe volgens die eise van God self ... Hierdie kommunikasie tussen God en mens kan alleen plaasvind deur die werking van die Heilige Gees. Sonder die werk van die Heilige Gees bly daar vir die mens 'n bedekking oor die Woord van God, die mens se verstand bly verduister, die geloof bly 'n onmoontlikheid. Sonder die werking van die Heilige Gees praat God met die mens, maar die mens kan nie antwoord nie, daar is geen geloof, geen reaksie nie. ${ }^{57}$ )

Dit is die wil van God dat die waarheid van Jesus Christus gekommunikeer word met die hele wêreld. ${ }^{58)}$ Die besondere wyse waarop hierdie waarheid na die wêreld gebring moet word, is deur al die nasies te maak tot dissipels van Jesus Christus: deur hulle te doop in die Naam van die Vader, die Seun en die Heilige Gees en hulle te leer om alles te onderhou wat Hy beveel het. ${ }^{59)}$ Dit moes plaasvind deur die getuienis van die apostels aangaande Jesus Christus in Judea en Samaria tot in die uithoeke van die wêreld. ${ }^{60)}$

Uit hierdie opdrag kan in breë trekke afgelei word dat die besondere wyse waarop Christus na sy hemelvaart met die wêreld wil handel, is deur middel van die bediening van Woord en sakrament wat Jesus Christus self tot inhoud het.

\section{3}

$\mathrm{Na}$ die hemelvaart het die apostels hierdie taak gaan uitvoer. Die kern van hulle taak was verkondiging. In Handelinge en in die briewe kry ons in breë trekke baie gegewens in verband met hierdie verkondiging. ${ }^{60 a)}$ Hoewel ons hierdie "gesproke en geskrewe" verkondiging nie sonder meer met ons prediking kan gelykstel nie, is 
dit seker legitiem om die kernaspekte daarvan op ons prediking van toepassing te maak.

Uit Handelinge en die briewe is dit duidelik dat die verkondiging 'n effektiewe kommunikatiewe handeling was. Die akte van verkondiging het reaksie by die hoorders tot gevolg gehad.

Die gevolg van die verkondiging is dat die hoorders diep in die hart getref is ${ }^{61)}$ hulle het ag gegee op die woord van Filippus, ${ }^{62)}$ hulle het die woord aangeneem, ${ }^{63)}$ hulle het geglo in Jesus Christus. ${ }^{64}$

Die verkondiging van Petrus het op hulle so 'n magtige indruk gemaak dat hulle diep in die hart getref is. As hulle die boodskap van Petrus hoor, besef hulle hierdie boodskap is vir hulle tot heil of tot oordeel. Die werkwoord "getref" beskryf 'n bepaalde gemoedsbeweging. ${ }^{65)}$ Hulle is bedroef oor hulle sonde "all the guilt of their unbelief was revealed through Peter's sermon."66) Die negatiewe lei egter tot die positiewe. Hulle is terneergedruk maar tegelyk ook gewillig om te luister na die Woord. ${ }^{67}$ Die feit dat hulle ag gee op die Woord beteken daar was 'n ernstige begeerte by hulle om die Woord te hoor. Hulle akte van hoor was nie oppervlakkig nie, hulle het met volle aandag geluister. Hulle het nie alleen gehoor nie, daar was 'n "favourable response". ${ }^{68)}$ Waar daar in genoemde tekse miskien nog enige twyfel bestaan of die hoorders na die verkondiging werklik tot geloof gekom het, word dit in Handelinge 8:12, 8:37, 10:47, 13:48 en 17:4 bevestig.

Die verkondiging wat deur die werking van die Heilige Gees mense bring tot die geloof in Christus, bring dieselfde mense tot die openlike belydenis van Christus voor die wêreld. ${ }^{69)}$ Tekskrities is hier die probleem dat die Nestle teks en ander gesaghebbende manuskripte nie hierdie teks bevat nie. ${ }^{70)}$ Die teks beskryf egter algemene Christelike gebruik in dié tyd en is dit daarom volkome geregverdig om dit te handhaaf, al sou die kamerling nou nie juis presies so bely het nie. ${ }^{71)}$ Die kamerling se geloof wat deur sy belydenis tot uitdrukking kom, is geen oppervlakkige geloof nie. Met sy belydenis bely hy alles wat die Bybel aangaande Christus leer. ${ }^{72)}$

Die gevolg van die hoorders se geloof is, dat God hulle toegevoeg het tot die gemeente. ${ }^{\text {7) }}$ Hierdie toevoeging het geskied deur die sigbare handeling van die doop. ${ }^{74}$ Dat hulle deur die doop daadwerklik tot die gemeente toegevoeg is, word beklemtoon deur die feit "that they were added by baptism on that very day and not that they were added that day but were baptized later on."75) God voeg die gelowiges toe tot die gemeente deur die doop maar dit eers nadat die Woord aan hulle verkondig is. ${ }^{76}$ In Handelinge tref ons die vaste skema aan: verkondiging - geloof - doop of miskien in die lig van 8:37: verkondiging - geloof - belydenis - doop. ${ }^{\text {m) }}$

Dat die verkondiging nie sonder meer selfwerkende krag het nie, blyk uit die feit dat die reaksie op die verkondigde Woord nie oral 
by almal dieselfde is nie. Slegs "'n deel van die luisterende Jode" het die woord van Petrus aanvaar. Dit gebeur nie altyd, "dat al degenen die de stem van den mensch in hunne ooren opvangen, ook te gelijker tijd den Geest in zich opnemen. ${ }^{178)}$

Nadat die Woord gehoor is, die geloof gevolg het, die betrokkenes deur die doop deel geword het van die gemeente, volg daar 'n bepaalde lewe in die gemeente. Hulle het volhard in die leer van die apostels. Hulle het voortgegaan om te luister na die verkondiging en is langs hierdie weg dieper ingelei in die waarheid van God. ${ }^{79}$ Langs hierdie weg is hulle versterk in die geloof en is die gemeente opgebou tot eer van God. Hulle het nie alleen die een sakrament naamlik die doop ontvang nie, maar is deur die ontvangs daarvan op weg geplaas na die volgende naamlik die nagmaal. Op hierdie weg is hulle begelei deur die voortdurende verkondiging van die Woord. Woord en sakrament, onlosmaaklik aan mekaar verbonde, het gedien tot versterking van hulle geloof in die gemeente. Voorts is hulle deur die verkondiging van die Woord op weg geplaas na hulle medemens toe: die barmhartigheidsdiens het 'n sentrale plek ingeneem. Deurdat hulle volhard het in die gebed, wat ' $n$ integrale deel van die erediens is, kan gesê word dat hulle gereeld in erediens bymekaar gekom het en dat die reeds genoemde drie elemente ' $n$ integrale deel van die erediens was.

Volgens Handelinge 13:42-49 het die gelowiges selfs begin om getuie te wees van Jesus Christus. "The talk about Paul and Barnabas and the sermon the former had preached spread through the city, the proselytes telling all their Greek friends with the result that a vast interest was aroused, and almost the whole city turned out to hear the Word of God. ${ }^{180)}$ Die wat die evangelie gehoor het, het dit weer aan ander verkondig.

'n Groot deel van hulle wat die Woord gehoor het, het Petrus gevolg. ${ }^{81)}$ Calvijn sien in hierdie "volg" 'n pastorale element, want volgens hom laat God mense wat tot die geloof gekom het nie ledig sit tot die volgende Sondag nie. ${ }^{82)}$ Die verkondiging van die Woord in een gestalte maak ander gestaltes noodsaaklik. ${ }^{83)}$ Die vrugte van die verkondiging is in die eerste plek nie tot roem van die mens nie, maar tot eer van God. ${ }^{84)}$

Paulus se briewe gee vir ons hoofsaaklik die inhoud van sy verkondiging weer. Uit Romeine 10:17 is dit egter duidelik dat Paulus geoordeel het dat die verkondiging, wat Jesus Christus tot inhoud het, lei tot die geloof in Christus.

Dit spreek eintlik vanself dat Paulus verwag het dat die inhoud van sy verkondiging deur die gemeentes gehoor moes word en uitgeleef word. As ons kyk na al die temas wat in sy prediking aan die orde kom, kan ons sê dat hy met sy prediking mense wou lei tot 
die geloof in Jesus Christus en in hierdie geloof bewaar.

Geloof beteken vir hom: ten volle alles van die drie-enige God verwag en met al jou vermoëns Hom dien en gehoorsaam wees binne die raamwerk van sy Kerk.

Opsommend kan ons sê dat die verkondiging gedurende die eerste eeue van die Christelike Kerk kommunikatief-effektief was. Die verkondiging het die hoorders in die hart getref, hulle het die Woord aangeneem, hulle het geglo in Jesus Christus, hulle het volhard in die geloof, hulle het deel geword van die gemeente, geluister na die prediking, die sakramente gebruik, gebid, offergawes gegee en gehandel volgens die eise van Gods Woord. In kort: Die gevolg van die verkondiging was: Hulle was gelowiges soos dit God welbehaaglik is.

Hierdie kommunikatief-effektiewe verkondiging het 'n bepaalde inhoud gehad:

Die inhoud van die verkondiging in die vroeg-Christelike kerk was Jesus Christus. Deur te sê Christus is die inhoud van die verkondiging kan baie beteken. Daarom is dit nodig dat dit nader omskryf sal word. As gesê word dat Christus die inhoud van die verkondiging van die vroeg-Christelike kerk is, beteken dit Christus soos Hy geopenbaar is. Op grond hiervan moet dadelik gesê word Christus is in die verkondiging nie voorgehou as ' $n$ ideale tipe van 'n religieuse persoonlikheid nie, ook nie as die groot sosiale hervormer en maatskaplike opheffingswerker nie maar as die Verlosser van die mens uit sonde en dood. ${ }^{85)}$ Die vroeg-Christelike kerk se verkondiging van Jesus Christus kan die beste omskryf word in die woord van die Apostolicum: Jesus Christus, sy eniggebore Seun, ons Heer; wat ontvang is van die Heilige Gees, gebore uit die Maagd Maria, wat gely het onder Pontius Pilatus, gekruisig, gestorwe en begrawe is en neergedaal het na die hel, wat op die derde dag weer opgestaan het uit die dode, opgevaar het na die hemel en sit aan die regterhand van God die almagtige Vader, vanwaar Hy sal kom om te oordeel die wat nog lewe en die wat reeds gesterf het. Selfs onder die filosofiese heidene het die verkondiging nie 'n ander inhoud gehad nie. ${ }^{86}$ ' $n$ Integrale deel van die verkondiging was dat die hoorders opgeroep word om te glo in hierdie Christus wat aan hulle verkondig word as die enigste Verlosser uit sonde en dood. ${ }^{87)}$

Die verkondiging het nie plaasgevind vanuit die ervaring nie maar vanuit die openbaring soos die Skrifte daarvan getuig en soos die apostels dit self gesien het in Jesus Christus. Petrus se verkondiging geskied vanuit die Skrif en die selfopenbaring van Jesus Christus. Hy gaan uit van Joël 2:28-32, haal Psalm 16;8-11 en Psalm 110:1 aan en spreek alleen van Christus soos hy self van sy verskyning getuie was. ${ }^{88)}$ Ook Paulus verkondig Christus vanuit die Ou-Testamentiese openbaring. ${ }^{89)} \mathrm{Hy}$ doen dit eers nadat die Ou Testament voorgelees 
is. ${ }^{90)}$ Hy spreek alleen direk van Christus omdat Christus ook aan hom verskyn het. Selfs Filippus gaan in sy verkondiging uit van die Skrif. ${ }^{91)}$ Die apostel Paulus se verkondiging word omskryf met die woorde: "Hy het die hele raad van God verkondig" (anagelai pasan tēn boulēn tou Theou). ${ }^{92)}$ Die "hele raad van God" is volgens Calvijn die ganse openbaring van God soos die Skrifte daarvan getuig. Die raad van God is opgeteken in die Skrif en mag nêrens anders gesoek word nie. Hierdie feit dat die hele raad van God verkondig is, het volgens Calvyn besondere betekenis vir die verkondiging van alle tye. Hiervolgens word aan die oordeel van die verkondiger nie oorgelaat wat hy wil verkondig en wat hy graag wil weglaat nie. Dit weerhou die verkondiger ook daarvan om iets anders te verkondig as die inhoud van die Heilige Skrif. ${ }^{93)}$

Die verkondiging is gebonde aan die openbaring van God soos die Skrifte daarvan getuig. Hiermee word indirek gesê dat die verkondiging geen willekeurige spel is wat op menslike goeddunke gegrond is nie, maar verkondiging is volgens die eis van God. Reeds hier word getoon dat vir die toekomstige verkondiging van die kerk, die leer van die kerk, soos vervat in die belydenis en belydenisskrifte, ' $n$ noodsaaklike vereiste sou wees.

In Paulus se briewe is die kern van sy verkondiging: Jesus Christus, wat gekruisig is vir die sonde van die wêreld tot verlossing van elkeen wat in Hom glo.94)

Christus is die kern van sy boodskap. Hierdie boodskap word egter deurgetrek om feitlik elke aspek van die mens se lewe te raak. Net in sy Romeine- en Korintiër-briewe alleen is die volgende temas aan die orde: Die Nuwe-Testamentiese gelowiges moet nog God se wet gehoorsaam, ${ }^{95)}$ die besnydenis het nie meer waarde nie; ${ }^{96)}$ alle mense is van nature verlore; ${ }^{97}$ die geloof in Jesus Christus is die enigste weg tot die saligheid, ${ }^{98)}$ die lewe deur die Gees; ${ }^{99)}$ die toekomstige heerlikheid, ${ }^{100)}$ niks kan ons skei van die liefde van Christus nie; ${ }^{101)}$ die verkiesing van Israel; ${ }^{102)}$ God alleen moet geëer word; ${ }^{103)}$ riglyne vir die alledaagse lewe; ${ }^{104)}$ verpligtinge teenoor die owerheid; ${ }^{105)}$ broederliefde; ${ }^{106}$ verdeeldheid in die gemeente; ${ }^{107}$ onsedelikheid in die gemeente; ${ }^{108)}$ hofsake tussen gelowiges; ${ }^{109)}$ raad oor die huwelik; ${ }^{110}$ hoofbedekking by die erediens; ${ }^{111}$ viering van die nagmaal, ${ }^{122}$ verskeidenheid van geestesgawes; ${ }^{113)}$ opstanding ${ }^{144)}$ en offergawes. ${ }^{115)}$

In die hele proses van verkondiging neem die werk van die Heilige Gees ' $n$ sentrale plek in. (Vanweë die wye omvang beperk ons ons slegs tot Handelinge).

Op Pinksterdag begin die apostels meteens om die evangelie van Jesus Christus te verkondig. ' $n$ Deel van die skare dink hulle is vol soet wyn. Petrus sê nee, die verkondiging is alleen moontlik want die 
Heilige Gees is uitgestort. ${ }^{116)}$ Die vermoë om die evangelie te verkondig het hy seker nie deur sy studie of inspanning verkry nie, maar dit was ' $n$ gawe van die Heilige Gees. ${ }^{117)}$ Die apostels, voorheen ruwe, onbeskaafde, gebore in 'n veragtelike agterhoek, kan meteens oor goddelike sake en hemelse wysheid spreek. ${ }^{118)}$ In Handelinge 8 en 10 speel die hele verkondiging af in opdrag van die Heilige Gees. Die verkondiging is eers moontlik deur die Heilige Gees.

Die oorsprong en voorgang van die verkondiging onder die heidene word ook beskryf as ' $n$ gebeure wat direk onder leiding van die Heilige Gees gestaan het. ${ }^{119)}$ "Nu was de toestand deze, dat de Heilige Geest de ambtsdragers te Antiochië op de een of andere wijze te verstaan had gegeven, dat er iets geschieden moest." ${ }^{102)}$ Hulle bewandel nie hulle eie pad nie, maar hulle gaan as gestuurdes van die Here. Die ganse verkondiging onder die heidene wat volg na 13:2 en 4 beskryf De Boor as die gevolg van die Heilige Gees se roeping, uitsending en toerusting. ${ }^{121}$ )

Nie alleen is die verkondiging as sodanig die werk van die Heilige Gees nie, maar ook die vrugte van die verkondiging.

\section{Handelinge 2:37}

Alles wat plaasgevind het in die lewe van die mense na Petrus se verkondiging op Pinksterdag is die eerste gevolge van die uitstorting van die Heilige Gees. ${ }^{122}$ ) Beide die geloof en die toevoeging tot die gemeente was daad van die heilige Gees. Selfs die doop as sigbare teken van die toevoeging "was an outward mark of their having the Spirit. ${ }^{123}$ ) Die voortgaande lewe in die gemeente soos beskryf is vers 42 , is beskrywing van die toestand soos ons dit aantref onder die invloed van die uitstorting van die Heilige Gees. As daar volharding in die geloof is, is dit alleen die werk van die Heilige Gees. Niks kan die mens self in die geloof verwerf of besit voordat hy nie met die Heilige Gees begiftig is nie. Die Heilige Gees is inderdaad die sleutel wat vir die mens die deur open sodat hy kan ingaan in die koninkryk van God.

\section{Handelinge 8:15-17}

Dit lyk asof die vrugte van die geloof hier nie die gevolg is van die werk van die Heilige Gees nie, want volgens vers 16 het $\mathrm{Hy}$ nog nie op iemand geval nie. Dit kan egter nie beteken dat daar nog geen werkinge van die Gees in Samaria was nie, want geloof en bekering is nie moontlik sonder die Heilige Gees nie. ${ }^{124}$ Vir Calvyn is hierdie vers ook problematies. Die doop is die werk van die Heilige Gees en hoe kan hulle gedoop wees as die Gees nog nie op iemand geval het 
nie? Daar bly niks oor van die doop as dit losgemaak word van die Heilige Gees nie. "Het mag dus niet ontkend worden, dat de Samaritanen, die in waarheid Christus in den doop aangedaan hadden, ook met zijnen Heiligen Geest bekleed waren." Lukas spreek daarom nie hier van die gewone gawe van die Heilige Gees waardeur God ons tot sy kinders wederbaar nie, maar oor die besondere buitengewone gawes van die Heilige Gees. ${ }^{125)}$ Lenski sluit aan by Calvyn en stel: "The periphrastic pluperfect with upērchon instead of èsan, R.1121, is used, but this by no means intends to say that at this time these Samaritans had received no more than baptism from the Holy Spirit or, as some would say, baptism as a symbol so that through the apostles they were now to receive the Spirit himself." ${ }^{126)}$

\section{Handelinge 10:44}

Die geloof en doop van Kornelius is alleen moontlik omdat alles wat in Kornelius se huis plaasgevind het, in die teken van regstreekse ingrype deur God self staan. Kornelius en sy huis het nie net die Woord gehoor as afbeelding van 'n objektiewe waarheid nie maar as waarheid wat vir elkeen van hulle persoonlik plaasgevind het. Dit was alleen moontlik op grond van die werking van die Heilige Gees. God begiftig die heidene met sy Gees om daarmee te betuig dat ook hulle in die gemeenskap van die verbond opgeneem is.

Terwyl Petrus spreek is die Heilige Gees uitgestort. Van belang is veral die feit dat net soos Woord en sakrament nie geskei word nie, so ook Woord en Heilige Gees nie. Werking van die Heilige Gees sonder die verkondigde Woord moet sterk afgewys word. ${ }^{127}$

\section{Handelinge 13:48}

Hulle het gelowig geword wat verordineer is tot die ewige lewe. ${ }^{128)}$ Lukas wil nie hier spreek oor die predestinasie nie, maar klem lê op die feit dat die geloof ' $n$ gawe van God is deur die Heilige Gees. ${ }^{129}$ Volgens Lenski wil hierdie woorde die geloof toeskryf aan die werking van die Heilige Gees, maar die ongeloof aan die mens self. $\mathrm{Na}$ ' $\mathrm{n}$ volledige bespreking van die werkwoord "tassō" en die naamwoord "taksis" konkludeer hy: "Here we have a contrast: the Jews thrust away the Word; these Gentiles glorify the Word. By their own fault the Jews are out of the 'taksis', by God's grace these Gentiles are in it. Again the contrast: the Jews regard themselves unworthy of eternal life; these Gentiles are in line for eternal life. Who put them in line? God did so by sending Paul and Barnabas and his Word and his grace and by making both come in contact with their hearts. He did the same for the Jews and would have preferred to have them in the same blessed 'ordo' but for the criminal wickedness with which 
they removed themselves from this 'ordo' by blaspheming instead of glorifying the Word." 130 )

Selfs die vreugde van die geloof is die werk van die Heilige Gees. ${ }^{131)}$ Hulle was met vreugde vervul, omdat die genade van die Heilige Gees in hulle heerskappy gevoer het. ${ }^{132)}$ Die werking van die Heilige Gees het tot gevolg dat nieteenstaande alle nood daar nogtans geestelike blydskap is.

Ten slotte kan van die verkondiging soos ons dit aantref in Handelinge, gesê word: Dit het in die meeste gevalle plaasgevind deur die ampsdraers van die kerk. ${ }^{133)}$ Dat dit juis die ampsdraers van die kerk is wat moet verkondig "was the intention of Jesus when he appointed them to their office."

Wat die vorm van die prediking betref, tref ons in Handelinge en in die briewe nie ' $n$ vaste bepaalde vorm by elke geleentheid nie.

1 Soms geskied die verkondiging by wyse van 'n homelie, soms in die vorm van ' $n$ tweegesprek en soms in geskrewe vorm.

2 Die verkondiging is soms vertroostend, soms vermanend, soms bemoedigend. Soms is dit verhalend en dan weer onderrigtend van aard.

3 Volgens Bo-Reicke het die verkondiging in die vroeg-Christelike kerk gewoonlik uit drie dele bestaan, naamlik "These," Argumente en "Konklusion."

31 Die "These" bestaan uit die oer-christelike verklaring dat Jesus nieteenstaande sy vernedering die Here is (Hand. 2:36, 10:36 en 42 en 13:24-26).

32 Om hierdie "these" te bewys word verskillende "argumente" aangevoer, wat hoofsaaklik die volgende is:

321 Die Jode het Jesus, die heilige en gestuurde deur God, nieteenstaande al sy wonders, gedood en so die raad van God vervul (2:22-23, 10:37-39 en 13:27-28).

322 Die Heilige Skrif het die opstanding van Jesus Christus reeds vooraf aangekondig (2:24-31, 10:43(a) en 13:29 en 32-37).

323 Die apostels is ooggetuies van Christus se opstanding en laasgenoemde is die bewys dat Jesus die verhoogde Heer is (2:32, 20:40-41, 13:30-31).

33 Na hierdie "Argumenten" kom die "Konklusion", naamlik dat Jode, proseliete en heidene hulle moet bekeer tot Jesus en laat doop. ${ }^{135)}$ 
As die briewe van Paulus bygetrek word, moet gesê word dat die verkondiging ook baie sterk beskrywend was van hoe daar onder bepaalde omstandighede geglo en geleef moet word. Daar is ook baie sterk aangesluit by die konkrete situasie in die gemeente.

Bogenoemde beskrywing kan miskien dien as 'n algemene patroon van hoe die verkondiging verloop het, maar daar is nie sprake van dat dit enigsins ' $n$ bindende patroon was en is nie. 


\section{Gevolgtrekkings}

1 God wil dat die prediking by die hoorder bepaalde reaksies tot gevolg sal hê.

2 Hierdie reaksies is alleen moontlik deur die werking van die Heilige Gees.

3 Hierdie reaksies is: geloof in die drie-enige God en gehoorsaamheid aan Hom.

4 Om hierdie reaksies tot gevolg te hê, is 'n paar sake van die allergrootste belang:

41 Die prediking moet uitleg van die bepaalde teks of perikoop wees, nadat dit grondig geëksegetiseer is.

42 Die uitleg van die bepaalde teks of perikoop moet ooreenstem met die boodskap van die res van die Bybel so ver as wat dit ter sprake is.

43 Die uitleg van die bepaalde teks of perikoop moet ooreenstem met die bepaalde kerk se belydenisskrifte so ver as wat dit ter sprake is.

44 Die boodskap van die teks moet deurgetrek word om die mens in sy konkrete situasie aan te spreek. (Die prediking behoort baie duidelike riglyne te trek hoe 'n mens onder alle omstandighede moet glo en lewe.)

441 Die prediking in ' $n$ bepaalde gemeente moet sodanig wees dat dit in die verloop van 'n bepaalde tyd die hele "raad van God" aan die gemeente verkondig.

45 Teikengehoorontleding is noodsaaklik sodat die predikant sal weet vir wie hy preek.

46 Die predikant moet duidelik in verstaanbare taal preek.

47 Die predikant moet sover as moontlik sonder 'n manuskrip preek.

48 Hulpmiddele wat kan bydra om die boodskap duideliker te maak, sonder dat die inhoud skade aangedoen word en prinsipiële beginsels in verband met die prediking in gedrang kom, kan gebruik word.

49 Die beste moontlike tye moet gekies word om die erediens te hou.

410 Met die oog op 'n beter "verstaan" van die prediking sal dit goed wees as daar na die erediens tyd is vir bespreking van die bepaalde preek. 

word wat die besondere doel van die prediking is en hoedanig daar behoort gepreek te word.

\section{Voetnotas}

1 J I de Wet, Prinsipiële Homiletiek, Diktaatlesings, Universiteit van Pretoria, 1979.

2 G E Sweazey, Preaching the Good News, Prentice-Hall, Englewood Cliffs, New Jersey, 1976, bl 51-56.

3 C Heys, Grondbeginsels vir Geslaagde Kommunikasie, Die Kerk se Werk, Kongresreferate van die Werkgemeenskap vir Praktiese Teologie 1976-1978, NHW Pers, Pretoria, 1978, bl 16-25. Sien ook F W Blignaut en H P Fourie, Kommunikasiekunde, Inleidende Opstelle, UNISA, 1970.

4 C I Hovland en $W$. Weiss, The Influence of Source Credibility on Communication Effectiveness, soos aangehaal. C Heys, aw, bl 17.

5 Okke Jager, Baas Boven Buis, De Televisie in Theorie en Praktijk, soos aangehaal C Heys, aw, bl 17.

6 C Heys, aw, bl 19

7 M Joos, Semology; A Linguistic Theory of Meaning, soos aangehaal C Heys, aw, bl 19.

8 H P Fourie, Communication by objectives, soos aangehaal C Heys, aw, bl 20.

9 W D Jonker, Die Woord as opdrag, gedagtes oor die prediking, N G Kerkboekhandel, 1976, bl 80-89.

10 C Heys, aw, bl 19.

11 C Heys, Visuele Hulpmiddels, ongepubliseerde lesing tydens INSTRUCTA ' 80 by die R.A.U. gelewer.

12 H J C Pieterse, Skrifverstaan en Prediking, die verkondiging van Woordgebeure en vertoongebeure by Gerhard Ebeling as antwoord op die nood van die prediking, N.G. Kerkboekhandel Pretoria, 1979, bl 1-19

13 H J C Pieterse, aw, bl 12

14 H J C Pieterse, aw, bl 13

$15 \mathrm{~J}$ H v Wyk, Eksistensieteologie en Godsdiensonderrig, Pro Rege Pers Beperk, Potchefstroom 1971.

16 Leonhard Fendt, Homiletik, Theologie und Technik der Predigt, Töpelmann Berlin W. 35, bl 18.

17 G J Kotzé, Hedendaagse Skrifprediking, 'n Ondersoek na die Mistastinge in die Prediking van die Nuwere tyd, 'n Akademiese Proefskrif ter verkryging van die graad DD aan die Universiteit van Stellenbosch, 1963, Pro Rege Pers Beperk, Potchefstroom, 1963, bl 68.

18 Leitourgia Bd II, soos aangehaal G J Kotzé, aw bl 68.

19 G J Kotzé, aw, bl 70.

20 G J Kotzé, aw, bl 71.

21 G J Kotzé, aw, bl 73.

22 K. Barth. Die Prot. Theol., soos aangehaal G J Kotzé, aw, bl 79.

23 G Kotzé, aw, bl 111.

24 G J Kotzé, aw, bl 136.

25 K Dijk, De Dienst der Prediking, J H Kok N V Kampen, 1955.

26 H Jonker, Actuele Prediking, G F Callenbach - N V Nijkerk.

27 H Jonker, aw, bl 44.

28 H Jonker, aw, bl 61.

29 H D A du Toit, Homiletiese Eksegese, Hermeneutica, Erebundel aangebied aan prof. dr. E P Groenewald by geleentheid van sy 65 ste verjaarsdag, N.G. Kerkboekhandel Pretoria, 1970, bl 211-219.

30 G J Kotzé, aw, bl 172-256. 
31 K Barth, soos aangehaal G J Kotzé, aw, bl 174.

32 G J Kotzé, aw, bl 177.

33 G J Kotzé, aw, bl 225.

34 H J C Pieterse, aw, bl 19.

35 H J C Pieterse, aw, bl 118.

36 H J C Pieterse, aw, bl 120.

37 A G Barkley Wolf, Vensters in de Preek, Een Pleidooi voor het gebruik van illustraties in de Prediking, T Wever, Franker, 1968.

38 A G Barkley Wolf, aw, bl 45.

39 Dorothee Sölle, Politieke Theologie, Discussie met Rudolf Bultmann, Nederlandse vertaling Bosch en Kenning n.v. 1972.

40 Dorothee Sölle, aw, bl 49.

41 Dr. W H Velema, Politieke Prediking, Apeldeense Studies no. 5, J H Kock N.V. Kampen 1972, bl 27.

42 Dieter Trautwein, Kerkdienst Als Leerproces, J H Kok Kampen, 1974.

43 Dieter Trautwein, aw, bl 15.

44 Dieter Trautwein, aw, bl 36.

45 'n Driedaagse kursus oor visuele hulpmiddele R.A.U., Julie 1980.

46 Nederlandse Geloofbelydenis (NGB) Hoofstuk 29-31.

47 Heidelbergse Kategismus (HK) Vrg. en antw. 103.

48 H.K. Vrg. en antw. 65.

49 H.K. Vrg. en antw. 21.

50 Die Dordtse Leerreëls, (DL) hoofstuk 3 en 4:17.

51 DL. hfst. 3 en 4:10.

52 DL. hfst. 3 en $4: 11$.

53 DL. hfst. 3 en 4:9.

54 DL. hfst. 3 en $4: 17$.

55 Hebreërs 1:1.

56 B A Müller, Skrif en Kommunikasie, Die Kerk se Werk, aw, bl 5.

57 Joh 14:15-31, 16:5-15.

58 Joh 3:16.

59 Matt 28:19.

60 Hand 1:8.

60a Hierdie verkondiging kan ons nie in streng kompartemente indeel soos verkondigingsgestaltes vandag is nie.

61 Hand 2:37.

62 Hand 8:6.

63 Hand 2:41.

64 Hand 8:37.

65 E Haenchen, Die Apostelgeschichte neu überzetz und erklärt, Göttingen - Vandenhoeck und Ruprecht, 1961, bl 146.

66 R C H Lenski. The Interpretation of the Acts of the Apostles, Minneapolis Minnesota 1961, bl 103.

67 J Calvijn, De Handelinge der Apostelen, Verklaring van de Bijbel, Opnieuw uit het Latijn Vertaald deur ds. G Wielenga, W A de Groot Goudriaan, 1970, deel 1 bl 87.

68 F F Bruce, The Acts of the Apostles, The Greek Text with introduction and commentary, The Tyndale Press London, 1951, bl 183.

69 Hand. 8:37.

70 D E Nestle, Novum Testamentum Graece cum apparato artico curavit. D. Eberhard Nestle, novis curis elaboravit D Erwin Nestle Editio vicesima prima, Stuttgaart, Privileg. Württ. Bibelanstalt, 1952, bl 323.

71 F F Bruce, Kommentaar op Handelinge, aw, bl 194.

72 J Calvijn, Kommentaar op Handelinge 1, aw, bl 328.

73 Hand. 2:41.

74 W de Boor, Die Apostelgeschichte. Wuppertaler Studienbibel, R Brockhaus Verlag Wuppertal, 1965, bl 206.

75 R C H Lenski, Kommentaar op Handelinge, aw, bl 112.

76 E Haenchen, Kommentaar op Handelinge, aw, bl 147. 

I de Wet, Christusprediking, Hervormde Teologiese Studies, Vir die Bevorde- ring van die Bybels-Reformatoriese Teologie in Suid-Afrika, Jaargang 26, Afl. 1 en 2 bl 148.

86 Hand 17:18.

87 Hand 2:38-40, 8:37 en 16:31.

88 Hand $2: 25,30$ en $34,2: 22-36$ en $10: 34-43$.

89 Hand 13:17-27 en 17:2.

90 Hand 13:15.

91 Hand 8:32-35.

92 Hand 20:27.

93 J Calvyn, Kommentaar op Handelinge 11, bl 323, vgl. ook Nederlandse Geloofsbelydenis, artikel 7 Kerkboek, bl 3.

94 Rom 1:2, 1 Kor 2:2, 2 Kor 2:5.

95 Rom 2:12-16, 3:31, 6:15 - 7:25.

96 Rom 2:25-29.

97 Rom 3:9-20.

98 Rom 3:21-31.

99 Rom 8:1-17.

100 Rom 8:8-30.

101 Rom 8:31-37.

102 Rom 9:1-11:32

103 Rom 11:33-36 en 1 Kor 10:23-32.

104 Rom 12:9-21.

105 Rom 13:1-6.

106 Rom 14:1-23.

1071 Kor 1:10-17.

1081 Kor 5:1-13.

1091 Kor 6:1-11.

1101 Kor 7.

111 Kor 11:1-16.

1121 Kor 11:17-33.

1131 Kor 12-14.

1141 Kor 15.

1151 Kor 16:1-4 en 2 Kor 8:1-13.

116 Hand 2:17.

117 J Calvijn, Kommentaar op Handelinge 1, aw, bl 51.

118 J Calvijn, Kommentaar op Handelinge 1, aw, bl 54.

119 Hand. 13:2 en 4.

120 F W Grosheide, Korte Verklaring der Heilige Schrift, Kommentaar op Handelinge 1, bl. 195.

121 W de Boor, Kommentaar op Handelinge, aw, bl 235.

122 F W Grosheide, Korte Verklaring der Heilige Schrift, Kommentaar op Handelinge 1, aw, bl 41.

123 R C H Lenski, Kommentaar op Handelinge aw, bl 325.

124 F W Crosheide, Korte Verklaring der Heilige Schrift, Kommentaar op Handelinge 1, aw, bl 127.

125 J Calvijn, Kommentaar op Handeling 1, aw, bl 304.

126 R C H Lenski, Kommentaar op Handelinge, bl 325.

127 J Calvijn, Kommentaar op Handelinge 1, bl 417.

128 Vgl. ook Deuteronomium 6:14 Lukas 10:20 Filippense 4:3 Openbaringe 13:8, 20:12 en 21:27. 
129 W de Boor, Kommentaar op Handelinge, aw, bl 252.

130 R C H Lenski, Kommentaar op Handelinge, aw, bl 552.

131 Hand 13:52.

132 J Calvijn, Kommentaar op Handelinge 11, aw, bl 72.

133 Elke hoofstuk van Handelinge gee getuienis daarvan.

134 R C H Lenski, Kommentaar op Handelinge aw, bl. 70.

135 Bo Reicke, Glaube und Leben der urgemeinde, Zwingli- Verlag Zürich 1957, bl 45. 